\title{
Minimally Invasive Intracerebral Hemorrhage Evacuation Techniques: A Review
}

\author{
Theodore C. Hannah* ${ }^{\mathbb{D}}$, Rebecca Kellner and Christopher P. Kellner \\ Department of Neurosurgery, Icahn School of Medicine at Mt Sinai, New York, NY 10029, USA; \\ rebecca.kellner@icahn.mssm.edu (R.K.); christopher.kellner@mountsinai.org (C.P.K.) \\ * Correspondence: theodore.hannah@icahn.mssm.edu
}

Citation: Hannah, T.C.; Kellner, R.; Kellner, C.P. Minimally Invasive Intracerebral Hemorrhage Evacuation Techniques: A Review. Diagnostics 2021, 11, 576. https://doi.org/ 10.3390/diagnostics11030576

Academic Editor: Eytan Raz

Received: 18 February 2021

Accepted: 19 March 2021

Published: 23 March 2021

Publisher's Note: MDPI stays neutral with regard to jurisdictional claims in published maps and institutional affiliations.

Copyright: (c) 2021 by the authors. Licensee MDPI, Basel, Switzerland. This article is an open access article distributed under the terms and conditions of the Creative Commons Attribution (CC BY) license (https:/ / creativecommons.org/licenses/by/ $4.0 /)$.

\begin{abstract}
Intracerebral hemorrhage (ICH) continues to have high morbidity and mortality. Improving ICH outcomes likely requires rapid removal of blood from the parenchyma and restraining edema formation while also limiting further neuronal damage due to the surgical intervention. Minimally invasive surgery (MIS) approaches promise to provide these benefits and have become alluring options for management of ICH. This review describes six MIS techniques for ICH evacuation including craniopuncture, stereotactic aspiration with thrombolysis, endoport-mediated evacuation, endoscope-assisted evacuation, adjunctive aspiration devices, and the surgiscope. The efficacy of each modality is discussed based on current literature. The largest clinical trials have yet to demonstrate definitive effects of MIS intervention on mortality and functional outcomes for ICH. Thus, there is a significant need for further innovation for $\mathrm{ICH}$ treatment. Multiple ongoing trials promise to better clarify the potential of the newer, non-thrombolytic MIS techniques.
\end{abstract}

Keywords: minimally invasive surgery; intracerebral hemorrhage; SCUBA; MISTIE; ICH evacuation; neurosurgery

\section{Introduction}

Intracerebral hemorrhage (ICH) accounts for up to $20 \%$ of all strokes with 40,000 to 67,000 cases per year in the US [1,2]. Despite rapid and accurate diagnostic imaging techniques, the associated morbidity and mortality following ICH remains quite high. It has been estimated that only $20 \%$ of patients will ever regain full function and $40 \%$ die within one month [1,2]. Classically, ICH was been treated with medical management or craniotomy. Craniotomy intervention had been limited to those with superficial lobar or cerebellar bleeds causing significant neurological impairment [3]. The International Surgical Trial in Intracerebral Hemorrhage (STICH I) and STICH II trials compared surgical intervention to medical management, but could not definitively clarify surgery resulted in improved outcomes [3-5]. Research into the pathophysiologic mechanisms of ICH has demonstrated that $\mathrm{ICH}$ causes damage in two distinct and temporally separate mechanisms. First, the collection of blood within the brain causes mass effects leading to mechanical distortion and increased intracranial pressure (ICP). Elevated ICP leads to mitochondrial injury and aberrant neurotransmitter release. Second, the release of thrombin leads to infiltration of mesenchymal cells, microglia, and inflammatory cells resulting in significant perihematomal edema (PHE) [1]. PHE can cause additional neurological insult and some research asserts that PHE expansion accurately predicts ICH morbidity and mortality, but the true implications of PHE on outcomes remains controversial [6]. Nevertheless, improving ICH outcomes likely requires rapid removal of blood from the parenchyma and restraining edema formation while also limiting further neuronal damage due to the surgical intervention. Minimally invasive surgery (MIS) approaches promise to provide these benefits and, for this reason, have become alluring options for management of ICH. However, the results of rigorous clinical trials of MIS ICH methods over the past decade have been mixed. In addition to describing current methods of ICH diagnosis and 
prognosis, this article reviews the minimally invasive ICH evacuation methods and the literature describing each of their efficacies.

\section{Intracerebral Hemorrhage (ICH) Diagnosis and Imaging}

Similar to acute ischemic stroke patients, patients with ICH often present with rapid onset of impaired neurological function [1]. Accompanying symptoms can include headaches, seizures, elevated blood pressure, vomiting, and altered level of consciousness. A noncontrast head computed tomography (CT) is the standard neuroimaging technique that provides fast and accurate evaluation for the presence of ICH [2]. Once the diagnosis of ICH is made, clinicians may search for an underlying cause. CT angiography (CTA) is often ordered along with the non-contrast CT to evaluate for vascular pathologies [1].

In addition to the presence of hemorrhage and vascular pathologies, clinicians have begun to investigate various patterns and markers on these diagnostic images that predict ICH outcomes, the risk of rebleeding, and the overall benefit of acute surgical intervention. The most well-known imaging biomarker is the spot sign seen on CTA. The spot sign is defined as the presence of a tiny, enhancing foci within the hematoma on CTA caused by contrast extravasation [7]. It is suggestive of active bleeding and thus predicts hematoma expansion. Other signs that have been investigated include satellite sign, island sign, swirl sign, black hole sign, and blend sign (Figure 1). Unlike the spot sign, all of these markers are seen on non-contrast CT scans.

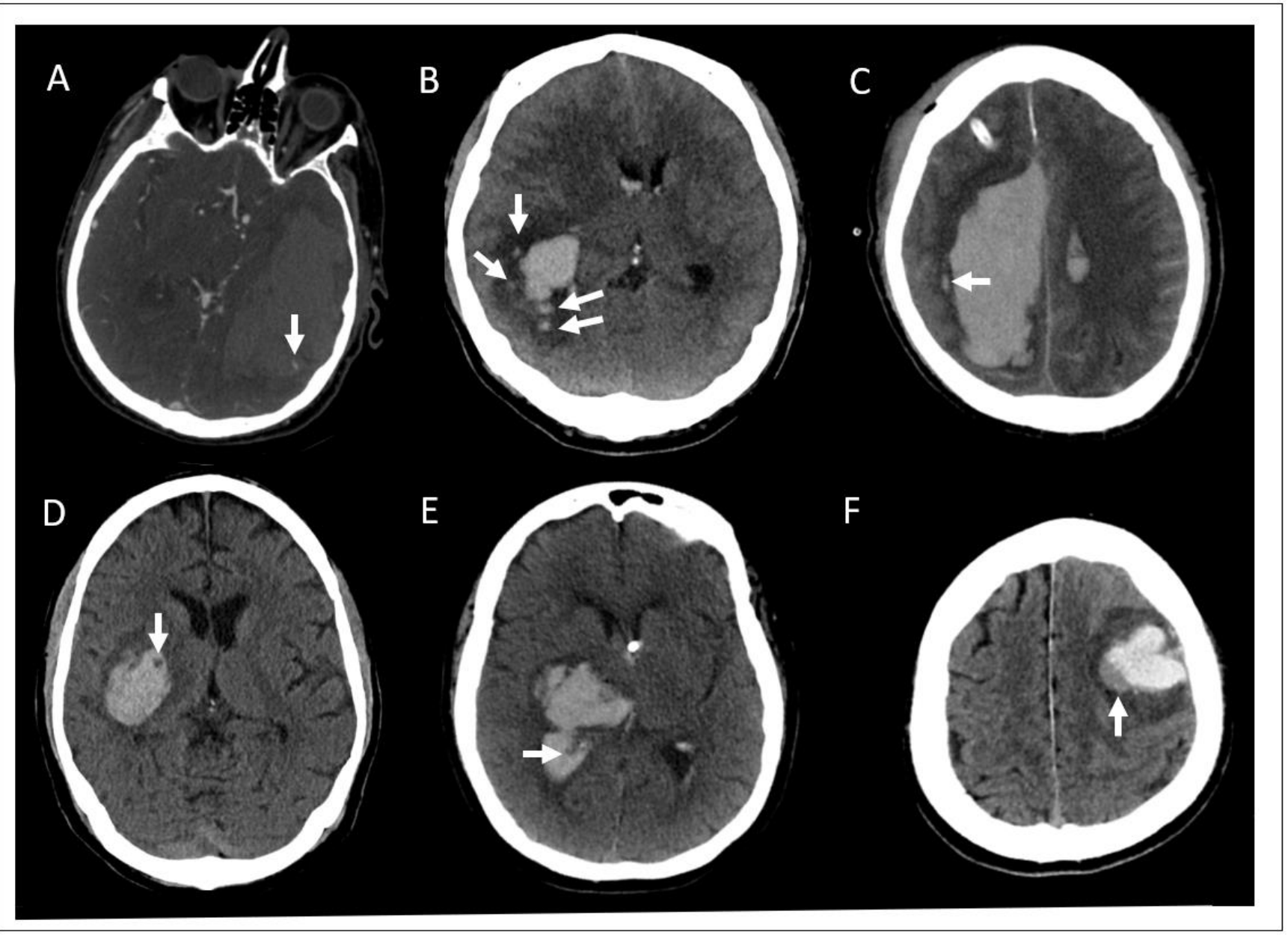

Figure 1. Diagnostic imaging markers associated with hematoma expansion in intracerebral hemorrhage. The various signs associated with hematoma expansion indicated by white arrows in each panel. Spot sign is seen on computed tomography angiography (CTA), the others are found on non-contrast computed tomography head (CTH). (A) Spot sign; (B) island sign; (C) satellite sign; (D) black hole sign; (E) swirl sign; (F) blend sign. 
The satellite sign and island sign are both considered shape markers [8,9]. The satellite sign is a small hemorrhage less than $10 \mathrm{~mm}$ in diameter and located within $20 \mathrm{~mm}$ of the main hematoma. It was present in $37-50 \%$ of patients and may be a useful predictor of hematoma expansion and poor functional outcomes, however, a meta-analysis demonstrated only a $50 \%$ sensitivity and $71 \%$ specificity for hematoma expansion [10-13]. Island sign is defined as at least three small hemorrhages separated from the main hematoma or at least 4 smaller hemorrhages connected to or separate from the main hematoma. It was present in 15-23\% of patients and has also been shown to predict hematoma expansion and poor outcomes [12,14-16]. Of note, one comparison study has suggested that the island sign is a better predictor of hematoma expansion than the satellite sign [12]. The swirl sign, black hole sign and blend sign are considered density markers [8,9]. The swirl sign is a low-density area within the hematoma surrounded by a hyper dense region with a poorly defined margin. Studies have found the swirl sign in approximately 30-35\% of patients. Although some studies have associated swirl sign with increased hematoma growth, multiple studies have found that it is not an independent predictor of expansion [17-20]. The black hole sign is a round or oval hypodensity completely surrounded by a hyperdense region with a well-defined border [21]. It was present in 14-22\% of patients studied and found to have low sensitivity, but very high specificity, in multiple studies for predicting hematoma expansion and worse functional outcomes [18,21-24]. The blend sign is a hypodense region within a hematoma that is directly adjacent to, but not encapsulated by, a hyperdense region with a well-defined border $[25,26]$. It was present in $16-20 \%$ of patients and was also shown to be highly specific for early hematoma growth [23,26-29]. Additionally, one study showed that the combination of the island sign and blend sign accurately predicted hematoma expansion in $92 \%$ of cases [25].

Overall, the spot sign has been found to be the most reliable predictor of the risk of hematoma expansion, however, if CTA is unobtainable, the non-contrast CT markers likely provide valuable information about the risk of hematoma growth [23]. Although these advances in $\mathrm{ICH}$ imaging interpretation are promising, one caveat researchers must be aware of is that the definition of some signs has varied between studies complicating assessment of those indicators [10,11]. Furthermore, the risks and benefits of surgical versus medical management in the presence of each of these imaging findings requires further study as the trials reviewed in the following sections of this article did not account for these imaging findings when evaluating outcomes or risk of rebleeding of the surgical intervention.

\section{Minimally Invasive Surgery (MIS) for ICH Techniques}

MIS ICH evacuation techniques have many similarities. Surgeons will use imaging reconstruction to determine the best trajectory and corresponding access point to approach the hematoma, taking care to avoid important brain regions and blood vessels. A small access point is made through the skull, then the instrumentation is introduced. Most protocols also require a follow-up computed tomography (CT) scan to determine evacuation efficacy. The differences between techniques are largely in the size of the access port and the instruments used to evacuate the blood clot. Another major point of differentiation is whether the technique involves the infusion of pharmacologic thrombolytics. Finally, there are also differences in the length of time that access to the clot needs to be maintained. Some methods drain the hematoma over days whereas others relinquish access to the clot by the end of the initial surgery. Here, we highlight the use of thrombolytics, the size of the instrumentation and associated burr hole, and when access to the clot is terminated (Figure 2). 

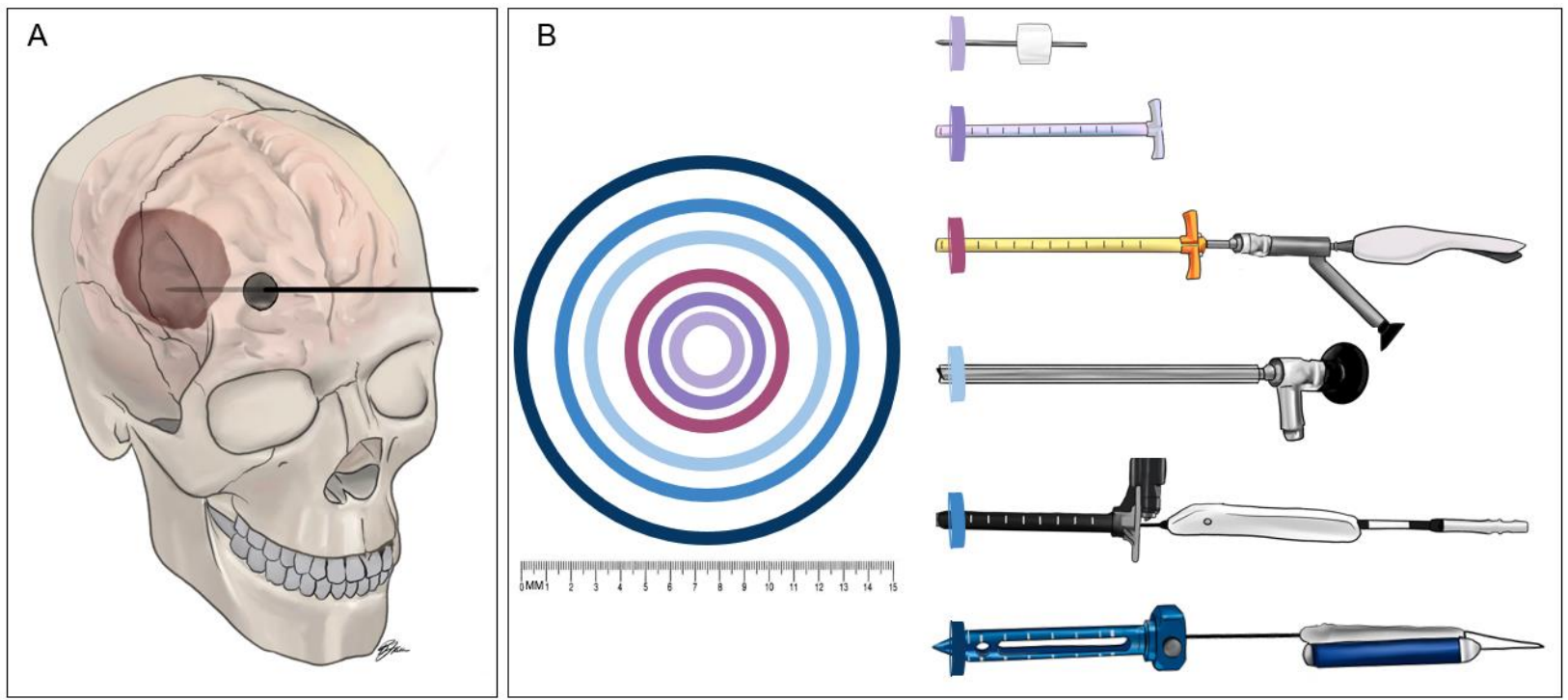

Figure 2. The relative sizes of the instruments of minimally invasive surgery for intracerebral hemorrhage (ICH) evacuation. (A) Generic sketch of the minimally invasive approach to intracerebral hemorrhage evacuation. A small craniotomy is made and the chosen device is inserted through the cranial opening and into brain parenchyma until reaching the hematoma. (B) Sketches of the ICH evacuation devices with concentric rings demonstrating the widest diameter of the instrument inserted through brain parenchyma for each technique. The color of each concentric ring corresponds to the color at the tip of the device in the illustrations. The devices, from top to bottom, are the craniopuncture YL-1 needle (outer diameter: $3.0 \mathrm{~mm}$ ), the $14 \mathrm{~F}$ vascular sheath used in the Minimally Invasive Surgery Plus Rt-PA for ICH Evacuation (MISTIE) procedure $(4.8 \mathrm{~mm})$, the Artemis device inserted through a $19 \mathrm{~F}$ vascular sheath and a 3-port Endoscope such as the Storz Lotta (6.3 mm), the clear sheath used during endoscope-assist procedures $(10.0 \mathrm{~mm})$, the Aurora Surgiscope $(11.5 \mathrm{~mm})$, and the BrainPath endoport $(15.8 \mathrm{~mm})$.

\section{Thrombolytic Techniques}

\subsection{Craniopuncture}

Craniopuncture is the standard of care for treating ICH in China [30]. Craniopuncture uses a YL-1 needle which consists of a $3 \mathrm{~mm}$-diameter hollow cannula containing the puncture needle. The puncture needle is drilled through the skull and into the hematoma before the cannula is fixed to the skull and the hematoma is aspirated. Following initial aspiration, a lysis fluid containing urokinase or recombinant tissue plasminogen activator (rtPA) is injected to facilitate further aspiration. The thrombolytic agent is reintroduced into the hematoma every 6-12 h. A follow-up CT scan is performed 1-3 days after initial drainage to measure the amount of blood remaining. The drainage needle remains in the brain for 3-5 days [30-32].

The landmark paper for craniopuncture was published in 2009 by Wang et al. [31]. They compared outcomes between craniopuncture and conservative medical management in 377 patients with basal ganglia hemorrhages $(25-40 \mathrm{~mL}$ in volume) in China (Table 1). The results showed significantly improved neurological function in the craniopuncture group by two weeks with no difference in the rate of rebleeding (9.7\% vs. 5.0\%). After three months, the percentage of patients with a modified Rankin Score (mRS) $>2$ was significantly smaller for those undergoing craniopuncture [31]. However, there was no significant difference in mortality. The following year, Sun and colleagues (2010) published a study demonstrating that craniopuncture also improved outcomes over traditional craniotomy [33]. However, different outcomes were found to be improved. Specifically, there was no improvement in neurological function at three months, but there was a significant decrease in the fatality rate and the rebleed rate (8.8\% vs. $21.4 \%)$ at 90 days for the craniopuncture. In 2011, Zhou et al. investigated differences between craniopuncture and traditional craniotomy and found no difference in the rebleed rate (10\% vs. $15.4 \%)$, or fatality rate at one year, but did show improvement across Glasgow Outcome Scale 
(GOS), mRS, and Barthel Index (BI) [34]. Thus, all three studies demonstrated a benefit of the craniopuncture, although whether the craniopuncture improves neurologic outcomes, mortality outcomes, or both, is less clear. Regardless, these results have led to the craniopuncture becoming the standard of care in China and craniopuncture techniques are now being tested in other hemorrhagic diseases such as chronic subdural and epidural hematomas [35,36]. Recently, the craniopuncture was also tested in an early intervention paradigm, defined as surgical intervention within six hours of symptom onset. Intriguingly, it was found that craniopuncture had worse rebleeding rates (40\% vs. $19 \%)$ and functional outcomes compared to craniotomy in the presence of the spot sign on CT. However, for patients without the spot sign, craniopuncture was equally efficacious as craniotomy had similar a rebleeding rate (12\% vs. $17 \%)$ [37]. However, there have been no clinical trials for craniopuncture in the US or Europe and thus craniopuncture is not commonly used in these regions. The most common thrombolytic MIS for ICH intervention used in the US is stereotactic aspiration with thrombolysis.

Table 1. Summary of major clinical trials for minimally invasive surgery for intracerebral hemorrhage evacuation techniques.

\begin{tabular}{|c|c|c|c|c|c|c|}
\hline Study & $\begin{array}{l}\text { Completed } \\
\text { or Ongoing }\end{array}$ & Device & $\begin{array}{c}\text { Dates of } \\
\text { Enrollment }\end{array}$ & Locations & $\begin{array}{l}\text { Number of } \\
\text { Subjects }\end{array}$ & Results \\
\hline $\begin{array}{l}\text { Wang et al., } \\
2009 \text { [31] }\end{array}$ & Completed & Craniopuncture & $\begin{array}{l}\text { January } 2003 \\
\text {-June } 2004\end{array}$ & $\begin{array}{l}42 \text { centers in } \\
\text { China }\end{array}$ & $\begin{array}{c}195 \\
\text { Craniopuncture } \\
\text { vs. } \\
182 \text { Conservative } \\
\text { medical } \\
\text { management }\end{array}$ & $\begin{array}{l}\text { Mortality: } \\
6.7 \% \text { vs. } 8.8 \%(p=0.44) \text { at } 90 \text { days } \\
\text { Functional Status: } \\
\text { significant improvement in } 90 \text {-day } \\
\text { Barthel Index }(\mathrm{BI})\left(\chi^{2}=23.13,\right. \\
p=0.0001) \\
\text { Rebleeding: } \\
9.7 \% \text { vs. } 5.0 \%, p=0.08\end{array}$ \\
\hline $\begin{array}{l}\text { Sun et al., } \\
2010 \text { [33] }\end{array}$ & Completed & Craniopuncture & $\begin{array}{l}\text { January } 2003 \\
\text {-July } 2005\end{array}$ & $\begin{array}{l}22 \text { centers in } \\
\text { China }\end{array}$ & $\begin{array}{l}159 \\
\text { Craniopuncture } \\
\text { with urokinase } \\
\text { infusion } \\
\text { vs. } \\
145 \text { Craniotomy }\end{array}$ & $\begin{array}{l}\text { Mortality: } \\
14.5 \% \text { vs. } 25.0 \%,(p=0.02) \text { at } 90 \text { days } \\
\text { Functional Status: } \\
\text { no difference in } 90 \text {-day BI }\left(\chi^{2}=4.166 \text {, }\right. \\
p=0.38) \\
\text { Rebleeding: } \\
8.8 \% \text { vs. } 21.4 \%, p=0.002\end{array}$ \\
\hline $\begin{array}{l}\text { Zhou et al., } \\
2011 \text { [34] }\end{array}$ & Completed & Craniopuncture & 2005-2008 & China & $\begin{array}{c}90 \\
\text { Craniopuncture } \\
\text { vs. } \\
\text { 78 Craniotomy }\end{array}$ & $\begin{array}{l}\text { Mortality: } \\
\text { 18.9\% vs. } 24.4 \%(p=0.39) \text { at } 365 \text { days } \\
\text { Functional Status: } \\
\text { BI }=79.5 \text { vs. } 62(p=0.01) \text {, at } 365 \text { days } \\
\text { Rebleeding: } \\
10.0 \% \text { vs. } 15.4 \%, p=0.29\end{array}$ \\
\hline $\begin{array}{c}\text { Stereotactic } \\
\text { treatment of } \\
\text { intracerebral } \\
\text { hematoma by } \\
\text { means of a } \\
\text { plasminogen } \\
\text { activator } \\
\text { (SICHPA) } \\
\text { [38] }\end{array}$ & Completed & $\begin{array}{l}\text { Stereotactic } \\
\text { aspiration } \\
\text { with throm- } \\
\text { bolytics }\end{array}$ & $\begin{array}{l}\text { March } 1996 \\
\text {-May } 1999\end{array}$ & $\begin{array}{l}13 \text { centers in } \\
\text { the Nether- } \\
\text { lands }\end{array}$ & $\begin{array}{c}36 \text { Surgical } \\
\text { vs. } \\
35 \text { Non-surgical }\end{array}$ & $\begin{array}{l}\text { Mortality: } \\
56 \% \text { vs. } 59 \%(p=0.78) \text { at } 180 \text { days } \\
\text { Functional Status: } \\
\text { no difference in likelihood of } \mathrm{mRS}>4 \\
(\mathrm{OR}=0.52, p=0.38) \\
\text { Rebleeding: } \\
0 \% \text { vs. } 22 \%, p=0.006\end{array}$ \\
\hline $\begin{array}{l}\text { Minimally } \\
\text { Invasive } \\
\text { Surgery Plus } \\
\text { Rt-PA for } \\
\text { ICH } \\
\text { Evacuation } \\
\text { Phase III } \\
\text { (MISTIE III) } \\
\text { [39] }\end{array}$ & Completed & $\begin{array}{l}\text { Stereotactic } \\
\text { aspiration } \\
\text { with throm- } \\
\text { bolytics }\end{array}$ & $\begin{array}{c}\text { December } \\
\text { 2013-August } \\
2017\end{array}$ & $\begin{array}{l}84 \text { centers } \\
\text { Australia, } \\
\text { Canada, } \\
\text { China, } \\
\text { Germany, } \\
\text { Hungary, } \\
\text { Israel, Spain, } \\
\text { UK, USA }\end{array}$ & $\begin{array}{l}255 \text { MISTIE } \\
\text { vs. } \\
251 \text { Standard } \\
\text { medical care }\end{array}$ & $\begin{array}{l}\text { Mortality: } \\
19 \% \text { vs. } 26 \%(p=0.04) \text {, at } 365 \text { days } \\
\text { Functional Status: } \\
\text { no difference in } \mathrm{mRS}<4 \text { at } 365 \text { days } \\
(45 \% \text { vs. } 41 \%,=0.33) \\
\text { Rebleeding: } \\
2 \% \text { vs. } 1 \%, p=0.32\end{array}$ \\
\hline
\end{tabular}


Table 1. Cont

\begin{tabular}{|c|c|c|c|c|c|c|}
\hline Study & $\begin{array}{c}\text { Completed } \\
\text { or Ongoing }\end{array}$ & Device & $\begin{array}{c}\text { Dates of } \\
\text { Enrollment }\end{array}$ & Locations & $\begin{array}{l}\text { Number of } \\
\text { Subjects }\end{array}$ & Results \\
\hline $\begin{array}{c}\text { Early } \\
\text { Minimally- } \\
\text { Invasive } \\
\text { Removal of } \\
\text { Intracerebral } \\
\text { Hemorrhage } \\
\text { (ENRICH) }\end{array}$ & Ongoing & Endoport & $\begin{array}{c}\text { December } \\
2016 \\
\text {-December } \\
2021\end{array}$ & $\begin{array}{l}36 \text { centers in } \\
\text { USA }\end{array}$ & $\begin{array}{c}\text { Expected } \\
\text { enrollment: } 300\end{array}$ & $\mathrm{n} / \mathrm{a}$-study ongoing \\
\hline $\begin{array}{l}\text { Auer et al. } \\
1989 \text { [40] }\end{array}$ & Completed & Endoscope & $\begin{array}{c}\text { June } 1983 \\
\text {-August } 1986\end{array}$ & Austria & $\begin{array}{l}50 \text { Endoscopic } \\
\text { evacuation } \\
\text { vs. } \\
50 \text { Medical } \\
\text { management }\end{array}$ & $\begin{array}{l}\text { Mortality: } \\
42 \% \text { vs. } 70 \%(p<0.01) \text { at } 180 \text { days } \\
\text { Functional Status: } \\
\text { significant difference in "minimal } \\
\text { neurologic deficit" at } 180 \text { days } \\
(40 \% \text { vs. } 25 \%, p<0.05) \\
\text { Rebleeding: } \\
4 \% \text { vs. } 30 \%, p<0.05\end{array}$ \\
\hline $\begin{array}{l}\text { Intraoperative } \\
\text { Stereotactic } \\
\text { Computed } \\
\text { Tomography- } \\
\text { Guided } \\
\text { Endoscopic } \\
\text { Surgery } \\
\text { (ICES) [41] }\end{array}$ & Completed & Endoscope & $\begin{array}{c}\text { August } 2005 \\
\text {-August } 2012\end{array}$ & $\begin{array}{c}29 \text { centers in } \\
\text { Canada, } \\
\text { Germany, } \\
\text { USA, UK }\end{array}$ & $\begin{array}{l}14 \text { Surgical } \\
\text { vs. } \\
4 \text { Medical }\end{array}$ & $\begin{array}{l}\text { Mortality: } \\
0 \% \text { vs. } 7.1 \%(p=0.68) \\
\text { Functional Status: } \\
\text { no difference in mRS }<4 \text { at } 180 \text { days } \\
(42 \% \text { vs. } 24 \%, p=0.19) \\
\text { Rebleeding: } \\
\text { no rebleeding in either group }\end{array}$ \\
\hline $\begin{array}{l}\text { Minimally } \\
\text { Invasive } \\
\text { Endoscopic } \\
\text { Surgery with } \\
\text { Apollo in } \\
\text { Patients with } \\
\text { Brain } \\
\text { Hemorrhage } \\
\text { (INVEST) }\end{array}$ & Ongoing & Apollo & $\begin{array}{c}\text { June } 2017 \\
\text {-June } 2021\end{array}$ & $\begin{array}{l}7 \text { centers in } \\
\text { USA }\end{array}$ & $\begin{array}{c}\text { Estimated } \\
\text { enrollment: } 50\end{array}$ & $\mathrm{n} / \mathrm{a}$-study ongoing \\
\hline $\begin{array}{l}\text { Artemis in } \\
\text { the Removal } \\
\text { of } \\
\text { Intracerebral } \\
\text { Hemorrhage } \\
\text { (MIND) }\end{array}$ & Ongoing & Artemis & $\begin{array}{c}\text { February } \\
2018 \text {-July } \\
2024\end{array}$ & $\begin{array}{l}20 \text { locations } \\
\text { in Germany } \\
\text { and USA }\end{array}$ & $\begin{array}{c}\text { Estimated } \\
\text { enrollment: } 500\end{array}$ & $\mathrm{n} / \mathrm{a}$-study ongoing \\
\hline $\begin{array}{c}\text { Dutch } \\
\text { Intracerebral } \\
\text { Hemorrhage } \\
\text { Surgery Trial } \\
\text { (DIST) }\end{array}$ & Ongoing & Artemis & $\begin{array}{l}\text { November } \\
2018 \text {-present }\end{array}$ & $\begin{array}{l}10 \text { centers in } \\
\text { the } \\
\text { Netherlands }\end{array}$ & $\begin{array}{c}\text { Estimated } \\
\text { enrollment: } 400\end{array}$ & $\mathrm{n} / \mathrm{a}$-study ongoing \\
\hline $\begin{array}{l}\text { Minimally } \\
\text { Invasive } \\
\text { Intracerebral } \\
\text { Hemorrhage } \\
\text { Evacuation } \\
\text { (MIRROR) }\end{array}$ & Ongoing & Surgiscope & $\begin{array}{c}\text { October } 2020 \\
\text {-October } 2028\end{array}$ & $\begin{array}{l}2 \text { centers in } \\
\text { USA }\end{array}$ & $\begin{array}{c}\text { Estimated } \\
\text { enrollment: } 500\end{array}$ & $\mathrm{n} / \mathrm{a}$-study ongoing \\
\hline $\begin{array}{l}\text { Ultra-Early, } \\
\text { Minimally } \\
\text { Invasive } \\
\text { Intracerebral } \\
\text { Hemorrhage } \\
\text { Evacuation } \\
\text { Versus } \\
\text { Standard } \\
\text { Treatment } \\
\text { (EVACUATE) }\end{array}$ & Ongoing & Surgiscope & $\begin{array}{c}\text { September } \\
2020 \\
\text {-December } \\
2025\end{array}$ & $\begin{array}{l}2 \text { centers in } \\
\text { Australia }\end{array}$ & $\begin{array}{c}\text { Estimated } \\
\text { enrollment: } 240\end{array}$ & $\mathrm{n} / \mathrm{a}$-study ongoing \\
\hline
\end{tabular}




\subsection{Stereotactic Aspiration with Thrombolysis}

The MISTIE trials refined and evaluated the stereotactic aspiration with thrombolysis procedure. After a patient is deemed eligible, they receive a second CT scan to evaluate the stability of the clot at least six hours following their initial diagnostic CT. If the clot proves stable, a trajectory is chosen and the surgeon drills a $1 \mathrm{~cm}$ burr hole at the appropriate site. Using image guidance, a $4.8 \mathrm{~mm}(14 \mathrm{~F})$ diameter sheath is stereotactically inserted into the middle of the hematoma's short axis and at least three quarters of the way along the long axis of the clot. The clot is then manually aspirated with a syringe until resistance is felt at which point a drainage catheter is inserted and the sheath is removed. The catheter is tunneled subcutaneously away from the burr hole and the incision is closed. The catheter is connected to a three-way stopcock to allow for injection of thrombolytics and saline in addition to drainage. Injections of rtPA start six hours after a post-operative CT scan demonstrates periprocedural clot stability. rtPA is then injected every eight hours and up to nine injections can be given. Injections are stopped after the ninth administration or once the clot is reduced to less than $15 \mathrm{~mL}$. CT scans are performed daily to measure remaining clot and assess clot stability. The catheter is allowed to drain for $24 \mathrm{~h}$ after sufficient reduction of the clot or $25 \mathrm{~h}$ after the last does of rt-PA before it is removed [30,32,39,42].

Prior to MISTIE, the Stereotactic Treatment of Intracerebral Hematoma by Means of a Plasminogen Activator (SICHPA) trials compared stereotactic aspiration with administration of urokinase to conservative management [38]. The results of this trial, published in 2003, showed no beneficial effect of this surgical technique on mortality or functional outcomes at 180 days. Since then, three phases of the MISTIE trials comparing stereotactic aspiration with thrombolysis to medical management have been published. Initial reports in 2008 suggested that the MISTIE protocol enhanced clot volume reduction over medical management [43]. Another study published at that time further suggested that introduction of the thrombolytic agent did not exacerbate PHE, which had been a significant concern [44]. In 2016, MISTIE-II trial results demonstrated that the MISTIE technique had similar safety outcomes as medical management, that MISTIE may improve mRS outcomes at 180 days likely due to an increase in volume reduction, and that it appeared the procedure reduced PHE relative to the amount of hematoma removed [41]. However, the $72 \mathrm{~h}$ rebleed rate was significantly higher using the MISTIE technique ( $27.8 \%$ vs. $9.5 \%)$. The efficacy results of MISTIE-III were published in 2019 [39]. There was no significant difference in the primary outcome of mRS at the one-year timepoint. However, there was significant improvement in mortality at one year for the surgical intervention group and, for those patients who achieved hematoma volume reduction to below $15 \mathrm{~mL}$, there was a significant improvement in mRS at one year. Although, the authors caution that these results are exploratory and some have noted that these results may be due to statistical chance $[39,45]$. A review of less rigorous studies of stereotactic aspiration with thrombolysis has revealed divergent results. For example, one study showed that it is less effective than craniotomy and endoscopic surgery in evacuating hematoma from cerebellar hemorrhages [46]. Other studies have demonstrated that this technique has better clinical outcomes in comparison to craniotomy for basal ganglia hemorrhage [47]. Meanwhile, a meta-analysis of studies comparing stereotactic aspiration with thrombolysis to craniotomy found improved mortality outcomes and lower rebleed rates for stereotactic aspiration ( $9 \%$ vs. $18 \%$ ) [48]. Nevertheless, the results of the MISTIE trial strongly support the need to evaluate other MIS ICH evacuation techniques.

\section{Non-Thrombolytic Techniques}

\subsection{Endoport-Mediated Evacuation}

The endoport-mediated evacuation method requires a $2.5-3 \mathrm{~cm}$ craniotomy at the access point and a subsequent $1.5-2 \mathrm{~cm}$ opening in the dura. The BrainPath endoport sheath (Nico Corp, Indianapolis, IN, USA) has a $15.8 \mathrm{~mm}$ diameter. Along with the inner obturator, the sheath is inserted through the access point to the deepest part of the clot. The obturator is then removed from the sheath providing surgeons with direct access to 
the hemorrhage. Removal of the clot can be performed with the Myriad handpiece (Nico Corp, Indianapolis, IN, USA), or common microsurgical tools. Coagulation of vessels and cavity irrigation with normal saline are also performed following evacuation of the clot. Upon completion of this procedure, the endoport is immediately removed $[30,32,49,50]$.

The Early Minimally-Invasive Removal of ICH (ENRICH) trial, investigating the benefits of endoport-mediated evacuation using the BrainPath and Myriad system is currently ongoing and the results are currently unknown. However, there have been a few preliminary studies investigating the efficacy of the BrainPath system. In a retrospective analysis of 11 patients, Przybylowski et al. (2015), found that the endoport permits at least $75 \%$ volume reduction of hematoma in most patients which improved mass effect, but outcomes were not compared to a control group [49]. Bauer et al. (2017) described their experience with BrainPath in $18 \mathrm{ICH}$ patients over two years at a single institution. They found that endoport-mediated evacuation was safe and effective, but also did not compare outcomes to a control group [50]. Griessenauer et al. (2018) compared five matched cases of endoport-mediated evacuation to endoscopic evacuation and found they had similar evacuation percentages, but that functional outcomes and mortality were poor in both groups [51]. The only multicenter case series was performed by Labib et al. (2017) [52]. In a review of 39 patients, they showed that endoport evacuation removed over $90 \%$ of the hematoma in $72 \%$ of patients and $52 \%$ of patients with available data had an mRS of two or less at the time of assessment, although the time to surgery varied widely throughout the cohort. There was also no control group for comparison. Consequently, it seems our understanding of the benefit of endoport-mediated evacuation may remain limited until the ENRICH trial findings are published.

\subsection{Endoscope-Assisted Evacuation}

The endoscope-assisted evacuation technique combines an endoscope with a multifunctional aspiration cannula working side by side through an access sheath. The endoscope provides visualization while the cannula allows the surgeon to aspirate the clot, irrigate the cavity, and cauterize blood vessels. These two tools are utilized together, often through a $10 \mathrm{~mm}$ diameter sheath. The procedure requires a craniectomy of $15-20 \mathrm{~mm}$ in diameter. The sheath is then inserted into the clot and the surgeon applies continuous suction while performing multiple rounds of irrigation and cauterizing blood vessels as necessary. The instruments and sheath are removed at the end of the procedure. At times, a drainage catheter is left in place and tunneled away from the incision $[30,32,53]$.

The first randomized study of an endoscope used in ICH evacuation was in 1989. Auer et al. found that endoscopic evacuation led to significantly lower mortality than medical management as well as a higher percentage of patients with minimal to no residual neurological deficits [40]. Since then, multiple other studies have been performed. Within the past decade, Nagasaka et al. (2011) retrospectively reviewed $23 \mathrm{ICH}$ patients treated with endoscopy versus 20 patients treated with craniotomy. Their results suggested increased evacuation rates and improved Glasgow Coma Scale (GCS) by day seven for the endoscopy group compared. One patient treated with craniotomy and zero patients treated with endoscopy had rebleeding [53]. In a retrospective review of 82 endoscope procedures versus 69 craniotomies, $\mathrm{Xu}$ et al. (2018) found that endoscope-assisted surgery resulted in a higher evacuation percentage and improved six-month mRS outcomes [54]. It was also associated with a decreased rebleeding rate ( $2 \%$ vs. $8 \%)$. However, a similar study by Wang et al. (2015) did not demonstrate comparably improved outcomes at the six month time point [55]. Likewise, Cai et al. (2017) found no difference in functional or mortality outcomes for endoscopy in comparison to craniotomy or stereotactic aspiration, although endoscopy did have greater evacuation percentages [56]. Conversely, another study comparing these three methods found that endoscopy and stereotactic aspiration had greater functional outcomes than craniotomy. It also suggested that endoscopy was a superior technique for patients with large bleeds of greater than $60 \mathrm{~mL}$ [57]. None of these three studies found a difference in rebleeding rate. The Intraoperative Stereotactic Computed 
Tomography-Guided Endoscopic Surgery (ICES) for Brain Hemorrhage arm of the MISTIE trial evaluated the efficacy of endoscopic evacuation. Over $40 \%$ had mRS below 4 at 180 and 365 days compared to just over $20 \%$ in the medical management group suggesting that endoscopic evacuation may improve functional outcomes [58]. To the best of our knowledge, there are no ongoing clinical trials specifically testing the endoscope-assisted evacuation technique. However, there have been two recent meta-analyses comparing endoscopic-assisted evacuation to craniotomy. In 2017, Ye and colleagues reviewed eight studies with 1327 patients in both randomized and non-randomized trials. They found that, in randomized control trials, endoscopic-assisted methods improved outcomes and reduced the total risk of complications, but had no effect on mortality in comparison to craniotomy [59]. In 2019, Nam et al. reviewed 3 randomized control trials with 289 subjects and showed that endoscopic-assisted techniques decrease mortality and complication rates in comparison to craniotomy [60]. The three studies in Nam et al. were also analyzed in Ye et al., however the inclusion criteria for Nam et al. was more stringent which may account for the divergent results on the effect of endoscopy on mortality. Similar to the results in studies evaluating craniopuncture, most endoscopy studies suggest there is a beneficial effect, but a rigorously conducted clinical trial will be necessary to determine if there is a true effect and which patients are most likely to benefit.

\subsection{Adjunctive Aspiration Devices}

Adjunctive aspiration devices permit enhanced operator control over aspiration strength reducing inadvertent damage to the brain structures encompassing the hematoma [61]. The Artemis System method of ICH evacuation, and its predecessor, the Apollo, are similar to endoscope-assisted techniques. Using the endoscope working channel, they combine an endoscope with the Artemis System (Penumbra, Alameda, CA, USA) into a single tool for aspiration and irrigation. There are multiple methods for evacuation using these devices, however, the stereotactic ICH Underwater Blood Aspiration (SCUBA) method has arguably become the most prominent. SCUBA leverages the Artemis System to maximize clot removal with variable suction and novel clot morcellation capabilities. Additionally, only a $10 \mathrm{~mm}$ craniectomy is necessary as the guidance sheath is $6.3 \mathrm{~mm}$ in diameter. Once the guide sheath is inserted to within $2 \mathrm{~cm}$ of the distal end of the clot, the introducer is removed and the endoscope/Artemis combination device is inserted. The SCUBA protocol has two phases. In the first, suction is turned to $100 \%$ while irrigation flow is at $25 \%$. Gentle exploration of the cavity is performed at that depth and all clot is removed. Then the endoscope is retracted back $1 \mathrm{~cm}$ and clot is removed at this depth. This process repeats until the endoscope reaches the proximal portion of the clot. Next, the suction is decreased to less than $25 \%$ of its maximum to decrease the likelihood of trauma to the cavity walls and irrigation is increased to $100 \%$. The infusion of saline prevents collapse of the cavity and permits the surgeon to find any remaining clot to be suctioned or leaking blood vessels to be cauterized. Once all the clot has been removed, the endoscope is removed [30,32,62-64].

The Apollo system proof of concept for ICH evacuation was first published in 2014. Since then interest in the use of adjunctive aspiration devices has grown considerably [62-64]. As evidence of this, there are currently three ongoing clinical trials investigating the Apollo or Artemis systems including the Minimally Invasive Endoscopic Surgery with Apollo in Patients with Brain Hemorrhage (INVEST) and Artemis in the Removal of Intracerebral Hemorrhage (MIND) studies in the US as well as the Dutch Intracerebral Hemorrhage Surgery Trial (DIST) trial in the Netherlands. Since the start of these trials, further case series have been published including one by Goyal et al. (2018) demonstrating a possible mortality benefit using the Apollo system over best medical management [65]. Most recently, a report of 100 patients undergoing MIS ICH evacuation with either Artemis or Apollo demonstrated that both are effective at reducing hematoma volumes to under $15 \mathrm{~mL}$ and, at 6 month follow-up, $46 \%$ of the patients had $\mathrm{mRS}<4$. The rebleed rate was 5\% [66]. Although this is the largest sample of patients treated with this 
ICH evacuation method, there was no comparison group and so the results of the INVEST, MIND and DIST trials are eagerly awaited.

\subsection{Surgiscope}

The newest instrument being used in MIS ICH evacuation is the Aurora Surgiscope System designed by Rebound Therapeutics. Cleared by the United States Food and Drug Administration (FDA) in January of 2019, it is the first disposable, single-use endoscope and has an outer diameter of $11.5 \mathrm{~mm}$. There have not yet been any published case series, however, interest is likely to grow in the near future as the first clinical trials of this device, Minimally Invasive Intracerebral Hemorrhage Evacuation (MIRROR) and Ultra-Early, Minimally Invasive Intracerebral Hemorrhage Evacuation Versus Standard Treatment (EVACUATE), have just recently begun enrolling patients.

\section{Conclusions}

ICH remains a devastating disease and analysis of mortality outcomes form 20002010 showed no decline in case fatality rates [67]. This highlights the need for improved interventions and MIS for ICH evacuation techniques remain the most likely candidate to achieve improved mortality outcomes. However, despite many reports of the benefits of various MIS for ICH evacuation methods, the exact nature of the benefit often differs between studies. Moreover, the largest clinical trials have yet to demonstrate definitive effects of surgical intervention on mortality and functional outcomes. Thus, there is a significant need for further innovation for ICH treatment and the multiple ongoing trials including ENRICH, INVEST, and MIND promise to better clarify the potential of the newer, non-thrombolytic MIS techniques.

Author Contributions: Conceptualization, C.P.K.; writing—original draft preparation, T.C.H.; writing-review and editing, T.C.H., R.K., C.P.K.; illustration R.K.; supervision, C.P.K. All authors have read and agreed to the published version of the manuscript.

Funding: This research received no external funding.

Institutional Review Board Statement: Not applicable.

Informed Consent Statement: Not applicable.

Data Availability Statement: Not applicable.

Conflicts of Interest: The authors declare no conflict of interest.

\section{References}

1. An, S.J.; Kim, T.J.; Yoon, B.-W. Epidemiology, risk factors, and clinical features of intracerebral hemorrhage: An update. J. Stroke 2017, 19, 3-10. [CrossRef]

2. Caceres, J.A.; Goldstein, J.N. Intracranial hemorrhage. Emerg. Med. Clin. N. Am. 2012, 30, 771-794. [CrossRef]

3. Hemphill, J.C.; Greenberg, S.M.; Anderson, C.S.; Becker, K.; Bendok, B.R.; Cushman, M.; Fung, G.L.; Goldstein, J.N.; Macdonald, R.L.; Mitchel, P.H.; et al. Guidelines for the management of spontaneous intracerebral hemorrhage. Stroke 2015, 46, 2032-2060. [CrossRef]

4. Mendelow, A.D.; Gregson, B.A.; Rowan, E.N.; Murray, G.D.; Gholkar, A.; Mitchel, P.M. Early surgery versus initial conservative treatment in patients with spontaneous supratentorial lobar intracerebral haematomas (STICH II): A randomised trial. Lancet 2013, 382, 397-408. [CrossRef]

5. Mendelow, A.D.; Gregson, B.A.; Fernandes, H.M.; Murray, G.D.; Teasdale, G.M.; Hope, A.; Larimi, M.; Shaw, D.; Barer, D.H. Early surgery versus initial conservative treatment in patients with spontaneous supratentorial intracerebral haematomas in the international surgical trial in intracerebral haemorrhage (STICH): A randomised trial. Lancet 2005, 365, 387-397. [CrossRef]

6. Urday, S.; Beslow, L.A.; Dai, F.; Zhang, F.; Battey, T.; Vashkevich, A.; Ayres, A.; Lasure, A.; Selim, M.; Simard, J.; et al. Rate of perihematomal edema expansion predicts outcome after intracerebral hemorrhage. Crit. Care Med. 2016, 44, 790-797. [CrossRef]

7. Wada, R.; Aviv Richard, I.; Fox Allan, J.; Demetrios, S.; Gladstone, D.; Tomlinson, G.; Symons, S. CT angiography “spot sign” predicts hematoma expansion in acute intracerebral hemorrhage. Stroke 2007, 38, 1257-1262. [CrossRef]

8. Morotti, A.; Boulouis, G.; Dowlatshahi, D.; Li, Q.; Barras, C.D.; Delcourt, C.; Yu, Z.; Zheng, J.; Zhou, Z.; Aviv, R.I.; et al. Standards for detecting, interpreting, and reporting noncontrast computed tomographic markers of intracerebral hemorrhage expansion. Ann. Neurol. 2019, 86, 480-492. [CrossRef] 
9. Sporns, P.B.; Kemmling, A.; Minnerup, J.; Hanning, U.; Heindel, W. Imaging-based outcome prediction in patients with intracerebral hemorrhage. Acta Neurochir. 2018, 160, 1663-1670. [CrossRef]

10. Yu, Z.; Zheng, J.; Ali, H.; Guo, R.; Li, M.; Wang, X.; Ma, L.; Li, H.; You, C. Significance of satellite sign and spot sign in predicting hematoma expansion in spontaneous intracerebral hemorrhage. Clin. Neurol. Neurosurg. 2017, 162, 67-71. [CrossRef]

11. Shimoda, Y.; Ohtomo, S.; Arai, H.; Okada, K.; Tominaga, T. Satellite sign: A poor outcome predictor in intracerebral hemorrhage. Cerebrovasc. Dis. 2017, 44, 105-112. [CrossRef] [PubMed]

12. Deng, L.; Zhang, G.; Wei, X.; Yang, W.S.; Li, R.; Shen, Y.Q.; Xie, X.F.; Lv, X.N.; Li, Y.L.; Zhao, L.B.; et al. Comparison of satellite sign and island sign in predicting hematoma growth and poor outcome in patients with primary intracerebral hemorrhage. World Neurosurg. 2019, 127, e818-e825. [CrossRef] [PubMed]

13. Yang, H.; Luo, Y.; Chen, S.; Luo, X.; Li, B.; Chen, S.; Zhou, Y.; Xia, Y. The predictive accuracy of satellite sign for hematoma expansion in intracerebral hemorrhage: A meta-analysis. Clin. Neurol. Neurosurg. 2020, 197, 106139. [CrossRef]

14. Li, Q.; Liu, Q.J.; Yang, W.S.; Wang, X.C.; Zhao, L.B.; Xiong, X.; Li, R.; Cao, D.; Zhu, D.; Wei, X.; et al. Island sign: An imaging predictor for early hematoma expansion and poor outcome in patients with intracerebral hemorrhage. Stroke 2017, 48 , 3019-3025. [CrossRef]

15. Wei, Y.; Zhu, G.; Gao, Y.; Chang, J.; Zhang, H.; Liu, N.; Tian, C.; Jiang, P.; Gao, Y. Island sign predicts hematoma expansion and poor outcome after intracerebral hemorrhage: A systematic review and meta-analysis. Front. Neurol. 2020, 11, 429. [CrossRef]

16. Zhang, F.; Zhang, S.; Tao, C.; Yang, Z.; You, C.; Yang, M. The comparative study of island sign and the spot sign in predicting short-term prognosis of patients with intracerebral hemorrhage. J. Neurol. Sci. 2019, 396, 133-139. [CrossRef]

17. Ng, D.; Churilov, L.; Mitchell, P.; Dowling, R.; Yan, B. The ct swirl sign is associated with hematoma expansion in intracerebral hemorrhage. Am. J. Neurorad. 2018, 39, 232-237. [CrossRef]

18. Xiong, X.; Li, Q.; Yang, W.S.; Wei, X.; Hu, X.; Wang, X.C.; Zhu, D.; Li, R.; Cao, D.; Xie, P. Comparison of swirl sign and black hole sign in predicting early hematoma growth in patients with spontaneous intracerebral hemorrhage. Med. Sci. Monit. 2018, 24, 567-573. [CrossRef]

19. Park, B.K.; Kwak, H.S.; Chung, G.H.; Hwang, S.B. Diagnostic value of swirl sign on noncontrast computed tomography and spot sign on computed tomographic angiography to predict intracranial hemorrhage expansion. Clin. Neurol. Neurosurg. 2019, 182, 130-135. [CrossRef]

20. Selariu, E.; Zia, E.; Brizzi, M.; Abul-Kasim, K. Swirl sign in intracerebral haemorrhage: Definition, prevalence, reliability and prognostic value. BMC Neurol. 2012, 12, 109. [CrossRef]

21. Li, Q.; Zhang, G.; Xiong, X.; Wang, X.C.; Yang, W.S.; Li, K.W.; Wei, X.; Xie, P. Black hole sign: Novel imaging marker that predicts hematoma growth in patients with intracerebral hemorrhage. Stroke 2016, 47, 1777-1781. [CrossRef] [PubMed]

22. Li, Q.; Yang, W.S.; Chen, S.L.; Lv, F.R.; Lv, F.J.; Hu, X.; Zhu, D.; Cao, D.; Wang, X.C.; Li, R.; et al. Black hole sign predicts poor outcome in patients with intracerebral hemorrhage. Cerebrovasc. Dis. 2018, 45, 48-53. [CrossRef]

23. Sporns, P.B.; Schwake, M.; Kemmling, A.; Minnerup, J.; Schwindt, W.; Niederstadt, T.; Schmidt, R.; Hanning, U. Comparison of spot sign, blend sign and black hole sign for outcome prediction in patients with intracerebral hemorrhage. J. Stroke 2017, 19, 333-339. [CrossRef] [PubMed]

24. Yu, Z.; Zheng, J.; Ma, L.; Guo, R.; Li, M.; Wang, X.; Lin, S.; Li, H.; You, C. The predictive accuracy of the black hole sign and the spot sign for hematoma expansion in patients with spontaneous intracerebral hemorrhage. Neurol. Sci. 2017, 38, 1591-1597. [CrossRef] [PubMed]

25. Huang, Y.W.; Yang, M.F. Combining investigation of imaging markers (island sign and blend sign) and clinical factors in predicting hematoma expansion of intracerebral hemorrhage in the basal ganglia. World Neurosurg. 2018, 120, e1000-e1010. [CrossRef] [PubMed]

26. Li, Q.; Zhang, G.; Huang, Y.-J.; Dong, M.-X.; Lv, F.-J.; Wei, X.; Chen, J.-J.; Zhang, L.-J.; Qin, X.-Y.; Xie, P. Blend sign on computed tomography: Novel and reliable predictor for early hematoma growth in patients with intracerebral hemorrhage. Stroke 2015, 46, 2119-2123. [CrossRef]

27. Li, Q.; Yang, W.-S.; Wang, X.-C.; Cao, D.; Zhu, D.; Lv, F.-J.; Liu, Y.; Yuan, L.; Zhang, G.; Xiong, X.; et al. Blend sign predicts poor outcome in patients with intracerebral hemorrhage. PLoS ONE 2017, 12, e0183082. [CrossRef]

28. Yu, Z.; Zheng, J.; Guo, R.; Ma, L.; Li, M.; Wang, X.; Lin, S.; Li, H.; You, C. Performance of blend sign in predicting hematoma expansion in intracerebral hemorrhage: A meta-analysis. Clin. Neurol. Neurosurg. 2017, 163, 84-89. [CrossRef]

29. Sporns, P.B.; Schwake, M.; Schmidt, R.; Kemmling, A.; Minnerup, J.; Schwindt, W.; Cnyrim, C.; Zoubi, T.; Heindel, W.; Niederstadt, T.; et al. Computed tomographic blend sign is associated with computed tomographic angiography spot sign and predicts secondary neurological deterioration after intracerebral hemorrhage. Stroke 2017, 48, 131-135. [CrossRef]

30. Hersh, E.H.; Gologorsky, Y.; Chartrain, A.G.; Mocco, J.; Kellner, C.P. Minimally invasive surgery for intracerebral hemorrhage. Curr. Neurol. Neurosci. Rep. 2018, 18, 34. [CrossRef]

31. Wang, W.Z.; Jiang, B.; Liu, H.M.; Li, D.; Lu, C.Z.; Zhao, Y.D.; Sander, J.W. Minimally invasive craniopuncture therapy vs. Conservative treatment for spontaneous intracerebral hemorrhage: Results from a randomized clinical trial in China. Int. J. Stroke 2009, 4, 11-16. [CrossRef]

32. Pan, J.; Chartrain, A.G.; Scaggiante, J.; Spiotta, A.M.; Tang, Z.; Wang, W.; Pradilla, G.; Murayama, Y.; Mori, R.; Mocco, J.; et al. A compendium of modern minimally invasive intracerebral hemorrhage evacuation techniques. Oper. Neurosurg. 2020, 18, 710-720. [CrossRef] 
33. Sun, H.; Liu, H.; Li, D.; Liu, L.; Yang, J.; Wang, W. An effective treatment for cerebral hemorrhage: Minimally invasive craniopuncture combined with urokinase infusion therapy. Neurol. Res. 2010, 32, 371-377. [CrossRef]

34. Zhou, H.; Zhang, Y.; Liu, L.; Han, X.; Tao, Y.; Tang, Y.; Hua, W.; Xue, J.; Dong, Q. A prospective controlled study: Minimally invasive stereotactic puncture therapy versus conventional craniotomy in the treatment of acute intracerebral hemorrhage. $B M C$ Neurol. 2011, 11, 76. [CrossRef] [PubMed]

35. Wang, Q.F.; Cheng, C.; You, C. A new modified twist drill craniostomy using a novel device to evacuate chronic subdural hematoma. Medicine 2016, 95, e3036. [CrossRef]

36. Zhao, X.; Jiang, H.; Liu, G.; Wang, T. Efficacy analysis of 33 cases with epidural hematoma treated by brain puncture under ct surveillance. Turk. Neurosurg. 2014, 24, 323. [CrossRef]

37. Ge, C.; Zhao, W.; Guo, H.; Sun, Z.; Zhang, W.; Li, X.; Yang, X.; Zhang, J.; Wang, D.; Xiang, Y.; et al. Comparison of the clinical efficacy of craniotomy and craniopuncture therapy for the early stage of moderate volume spontaneous intracerebral haemorrhage in basal ganglia: Using the cta spot sign as an entry criterion. Clin. Neurol. Neurosurg. 2018, 169, 41-48. [CrossRef]

38. Teernstra, O.P.M.; Evers, S.; Lodder, J.; Leffers, P.; Franke, C.; Blaauw, G.J.S. Stereotactic treatment of intracerebral hematoma by means of a plasminogen activator: A multicenter randomized controlled trial (SICHPA). Stroke 2003, 34, 968-974. [CrossRef]

39. Hanley, D.F.; Thompson, R.E.; Rosenblum, M.; Yenokyan, G.; Lane, K.; McBee, N.; Mayo, S.W.; Bistran-Hall, A.J.; Gandhi, D.; Mould, W.A.; et al. Efficacy and safety of minimally invasive surgery with thrombolysis in intracerebral haemorrhage evacuation (MISTIE III): A randomised, controlled, open-label, blinded endpoint phase 3 trial. Lancet 2019, 393, 1021-1032. [CrossRef]

40. Auer, L.M.; Deinsberger, W.; Niederkorn, K.; Gell, G.; Kleinert, R.; Schneider, G.; Holzer, P.; Bone, G.; Mokry, M.; Körner, E.; et al. Endoscopic surgery versus medical treatment for spontaneous intracerebral hematoma: A randomized study. J. Neurosurg. 1989, 70, 530-535. [CrossRef]

41. Hanley, D.F.; Thompson, R.E.; Muschelli, J.; Rosenblum, M.; McBee, N.; Lane, K.; Bistran-Hall, A.J.; Mayo, S.W.; Keyl, P.; Gandhi, D.; et al. Safety and efficacy of minimally invasive surgery plus alteplase in intracerebral haemorrhage evacuation (MISTIE): A randomised, controlled, open-label, phase 2 trial. Lancet Neurol. 2016, 15, 1228-1237. [CrossRef]

42. de Oliveira Manoel, A.L. Surgery for spontaneous intracerebral hemorrhage. Crit. Care. 2020, 24, 45. [CrossRef]

43. Morgan, T.; Zuccarello, M.; Narayan, R.; Keyl, P.; Lane, K.; Hanley, D. Preliminary findings of the minimally-invasive surgery plus rtpa for intracerebral hemorrhage evacuation (MISTIE) clinical trial. Acta Neurochir. Supp. 2008, 105, 147-151. [CrossRef]

44. Carhuapoma, J.R.; Barrett, R.J.; Keyl, P.M.; Hanley, D.F.; Johnson, R.R. Stereotactic aspiration-thrombolysis of intracerebral hemorrhage and its impact on perihematoma brain edema. Neurocrit. Care. 2008, 8, 322-329. [CrossRef]

45. Al-Shahi Salman, R.; Klijn, C.J.M.; Selim, M. Minimally invasive surgery plus alteplase for intracerebral haemorrhage. Lancet 2019, 393, 965-967. [CrossRef]

46. Li, L.; Li, Z.; Li, Y.; Su, R.; Wang, B.; Gao, L.; Yang, Y.; Xu, F.; Zhang, X.; Tian, Q.; et al. Surgical evacuation of spontaneous cerebellar hemorrhage: Comparison of safety and efficacy of suboccipital craniotomy, stereotactic aspiration, and thrombolysis and endoscopic surgery. World Neurosurg. 2018, 117, e90-e98. [CrossRef]

47. Shi, J.; Cai, Z.; Han, W.; Dong, B.; Mao, Y.; Cao, J.; Wang, S.; Guan, W. Stereotactic catheter drainage versus conventional craniotomy for severe spontaneous intracerebral hemorrhage in the basal ganglia. Cell Transplant. 2019, 28, 1025-1032. [CrossRef]

48. Wang, J.-W.; Li, J.-P.; Song, Y.-L.; Tan, K.; Wang, Y.; Li, T.; Guo, P.; Li, X.; Wang, Y.; Zhao, Q.-H. Stereotactic aspiration versus craniotomy for primary intracerebral hemorrhage: A meta-analysis of randomized controlled trials. PLoS ONE 2014, 9, e107614. [CrossRef] [PubMed]

49. Przybylowski, C.J.; Ding, D.; Starke, R.M.; Webster Crowley, R.; Liu, K.C. Endoport-assisted surgery for the management of spontaneous intracerebral hemorrhage. J. Clin. Neurosci. 2015, 22, 1727-1732. [CrossRef]

50. Bauer, A.M.; Rasmussen, P.A.; Bain, M.D. Initial single-center technical experience with the brainpath system for acute intracerebral hemorrhage evacuation. Oper. Neurosurg. 2017, 13, 69-76. [CrossRef]

51. Griessenauer, C.; Medin, C.; Goren, O.; Schirmer, C.M. Image-guided, minimally invasive evacuation of intracerebral hematoma: A matched cohort study comparing the endoscopic and tubular exoscopic systems. Cureus 2018, 10, e3569. [CrossRef]

52. Labib, M.A.; Shah, M.; Kassam, A.B.; Young, R.; Zucker, L.; Maioriello, A.; Britz, G.; Agbi, C.; Day, J.D.; Gallia, G.; et al. The safety and feasibility of image-guided brainpath-mediated transsulcul hematoma evacuation: A multicenter study. Neurosurgery 2017, 80, 515-524. [CrossRef]

53. Nagasaka, T.; Tsugeno, M.; Ikeda, H.; Okamoto, T.; Inao, S.; Wakabayashi, T. Early recovery and better evacuation rate in neuroendoscopic surgery for spontaneous intracerebral hemorrhage using a multifunctional cannula: Preliminary study in comparison with craniotomy. J. Stroke Cerebrovasc. Dis. 2011, 20, 208-213. [CrossRef]

54. Xu, X.; Chen, X.; Li, F.; Zheng, X.; Wang, Q.; Sun, G.; Zhang, J.; Xu, B. Effectiveness of endoscopic surgery for supratentorial hypertensive intracerebral hemorrhage: A comparison with craniotomy. J. Neurosurg. 2018, 128, 553-559. [CrossRef]

55. Wang, W.-H.; Hung, Y.-C.; Hsu, S.P.C.; Lin, C.-F.; Chen, H.-H.; Shih, Y.-H.; Lee, C.-C. Endoscopic hematoma evacuation in patients with spontaneous supratentorial intracerebral hemorrhage. J. Clin. Med. Assoc. 2015, 78. [CrossRef]

56. Cai, Q.; Zhang, H.; Zhao, D.; Yang, Z.; Hu, K.; Wang, L.; Zhang, W.; Chen, Z.; Chen, Q. Analysis of three surgical treatments for spontaneous supratentorial intracerebral hemorrhage. Medicine 2017, 96, e8435. [CrossRef]

57. Li, Y.; Yang, R.; Li, Z.; Yang, Y.; Tian, B.; Zhang, X.; Wang, B.; Lu, D.; Guo, S.; Man, M.; et al. Surgical evacuation of spontaneous supratentorial lobar intracerebral hemorrhage: Comparison of safety and efficacy of stereotactic aspiration, endoscopic surgery, and craniotomy. World Neurosurg. 2017, 105, 332-340. [CrossRef] 
58. Vespa, P.; Hanley, D.; Betz, J.; Hoffer, A.; Engh, J.; Carter, R.; Nakaji, P.; Ogilvy, C.; Jallo, J.; Selman, W.; et al. ICES (intraoperative stereotactic computed tomography-guided endoscopic surgery) for brain hemorrhage. Stroke 2016, 47, 2749-2755. [CrossRef]

59. Ye, Z.; Ai, X.; Hu, X.; Fang, F.; You, C. Comparison of neuroendoscopic surgery and craniotomy for supratentorial hypertensive intracerebral hemorrhage: A meta-analysis. Medicine 2017, 96, e7876. [CrossRef] [PubMed]

60. Nam, T.M.; Kim, Y.Z. A meta-analysis for evaluating efficacy of neuroendoscopic surgery versus craniotomy for supratentorial hypertensive intracerebral hemorrhage. J. Cerebrovasc. Endovasc. Neurosurg. 2019, 21, 11-17. [CrossRef]

61. Rothrock, R.J.; Chartrain, A.G.; Scaggiante, J.; Pan, J.; Song, R.; Hom, D.; Lieber, A.C.; Bederson, J.B.; Mocco, J.; Kellner, C.P. Advanced techniques for endoscopic intracerebral hemorrhage evacuation: A technical report with case examples. Oper. Neurosurg. 2020. [CrossRef]

62. Fiorella, D.; Arthur, A.; Schafer, S. Minimally invasive cone beam ct-guided evacuation of parenchymal and ventricular hemorrhage using the apollo system: Proof of concept in a cadaver model. J. Neurointerv. Surg. 2015, 7, 569-573. [CrossRef]

63. Spiotta, A.M.; Fiorella, D.; Vargas, J.; Khalessi, A.; Hoit, D.; Arthur, A.; Lena, J.; Turk, A.S.; Chaudry, M.I.; Gutman, F.; et al. Initial multicenter technical experience with the apollo device for minimally invasive intracerebral hematoma evacuation. Neurosurgery 2015, 11, 243-251. [CrossRef]

64. Turner, R.D.; Vargas, J.; Turk, A.S.; Chaudry, M.I.; Spiotta, A.M. Novel device and technique for minimally invasive intracerebral hematoma evacuation in the same setting of a ruptured intracranial aneurysm: Combined treatment in the neurointerventional angiography suite. Neurosurgery 2015, 11, 43-50. [CrossRef]

65. Goyal, N.; Tsivgoulis, G.; Malhotra, K.; Katsanos, A.H.; Pandhi, A.; Alsherbini, K.A.; Chang, J.J.; Hoit, D.; Alexandrov, A.V.; Elijovich, L.; et al. Minimally invasive endoscopic hematoma evacuation vs best medical management for spontaneous basalganglia intracerebral hemorrhage. J. Neurointev. Surg. 2019, 11, 579-583. [CrossRef] [PubMed]

66. Kellner, C.P.; Song, R.; Pan, J.; Nistal, D.A.; Scaggiante, J.; Chartrain, A.G.; Rumsey, J.; Hom, D.; Dangayach, N.; Swarup, R.; et al. Long-term functional outcome following minimally invasive endoscopic intracerebral hemorrhage evacuation. J. Neurointerv. Surg. 2020, 12, 489-494. [CrossRef]

67. Zahuranec, D.B.; Lisabeth, L.D.; Sánchez, B.N.; Smith, M.A.; Brown, D.L.; Garcia, N.M.; Skolarus, L.E.; Meurer, W.J.; Burke, J.F.; Adelman, E.E.; et al. Intracerebral hemorrhage mortality is not changing despite declining incidence. Neurology 2014, 82, 2180-2186. [CrossRef] 